\title{
Solid Waste Prediction using ANN in the Nagpur City
}

\author{
Mr. Shrikant R. Chaudhari ${ }^{1}$, Dr. Chitra A. Dhawale ${ }^{2}$ \\ Research Student, Dept of Electronics and Computer Science, R. T. M. Nagpur University, Nagpur (M.S.), India ${ }^{1}$ \\ Head, MCA Dept, Shri P.R. Pote Group of Educational Institutions, Amravati (MS) India ${ }^{2}$
}

\begin{abstract}
The objective of this paper is to predict the quantity of solid waste generated in Nagpur city. As population is increasing day by day solid waste generation is also increasing. This is very big question in front of NMC that how to tackle this problem. It is very important to predict the quantity of solid waste in the upcoming year to implement the best solid waste management system. Nagpur city is divided in to ten zones by NMC for better administration. Solid waste is collected from each zone and transferred at dumping station Bhandewadi, Nagpur. Solid waste prediction for the city like Nagpur is quite challenging as the values of the variables changes over the time rapidly. After studying the working of NMC, Nagpur city profile and literature review four factors, zone wise population, generated solid waste, slum population and electricity consumption in $\mathrm{KWh}$ /capita/day has been considered as most important factor in solid waste generation in the city. A radial basis function neural network mainly known for time series prediction is used in calculating the solid waste generated at Nagpur city. This work may be helpful to NMC for better implementation of solid waste management system.
\end{abstract}

Keywords: Nagpur Municipal corporation (NMC), Artificial Neural Networks (ANNs); Solid Waste Management System (SWMS); Neural Network (NN); Solid Waste (SW); kilo watt hour ( KWh); House Hold (HH).

\section{INTRODUCTION}

Nagpur is one of the important cities in Maharashtra State as well as in central India. Nagpur is famous for oranges and is known as the "Orange City". Nagpur is the sub capital of Maharashtra state. Nagpur city is having very vast area. It is divided in to 10 zones to implement best working system.

Population is increasing day by day and with respect to that solid waste generation is also increasing day by day. This is very big question in front of NMC that how to tackle this problem. Prediction of solid waste for the city like Nagpur is quite challenging as the values of the variables changes over the time rapidly. As per provisional reports of Census of India and given in [2].

\begin{tabular}{|l|l|l|l|}
\hline $\begin{array}{l}\text { Population } \\
\text { of Nagpur. } \\
(2011)\end{array}$ & $\begin{array}{l}\text { Literacy rate } \\
\text { of Nagpur }\end{array}$ & $\begin{array}{l}\text { Total } \\
\text { Slum } \\
\text { Population }\end{array}$ & $\begin{array}{l}\text { Slum } \\
\text { HH in } \\
\text { city }\end{array}$ \\
\hline $24,05,421$ & $93.13 \% \mathrm{t}$ & 858783 & 171645 \\
\hline
\end{tabular}

Source[2].

To handle the situation of solid waste management of Nagpur city it need to apply a technique which can predict the solid waste generation in the city in advance.

\begin{tabular}{|l|l|}
\hline Year & $\begin{array}{l}\text { Total Electricity } \\
\text { Consumption in Nagpur city }\end{array}$ \\
\hline $2000-01$ & $11,50,159$ \\
\hline $2010-11$ & $36,76,160$ \\
\hline
\end{tabular}

The number of slums in the city has increased from 424 slums in year 2002 to about 446 in year 2008. Of total 446 slum settlements in the city $287(65 \%)$ are notified [2]. Electricity Consumption in 000' KWh: 2010-11 by [1]. To calculate zone wise per capita consumption of electricity we have consider 500 unit (KWh)/capita/year [28].

Earlier work:- In the literature review, it is observed that many researcher have faced the problem of data availability, while making prediction of solid waste at Municipal corporation level. For prediction of solid waste we need quality and quantity of data.

Mr J Sudhir kumar [13] have considered four factors. He consider national level growth rate for the same factor. M Maleerat Sodanil \& Paiboon Chatthong [26] is having the same problem of data availability they have consider the only one factor i.e. generated solid waste from last 120 months.

In order to forecast time series for the amount of the solid waste generation in Bangkok he uses monthly solid waste as a variable. According to him, if the socioeconomic is used as variables, it makes non-performance model because of lack of monthly data.

Mr Vatsal Patel[16] mentioned that due to non-availability of adequate data on waste generation for low-income cities of the developing countries, integrated solid waste management is very challenging. He uses some dynamic factor as well as static factor for his research. 
Vol. 6, Issue 1, January 2017

Table 1.1 comparison of model on the basis of factors and dataset taken.

\begin{tabular}{|c|c|c|c|c|}
\hline Study area-> & Bangkok[26] & Elluru[13] & Gujarat towns[16] & Nagpur(proposed) \\
\hline NN used & $\begin{array}{l}\text { Multilayer } \\
\text { Perceptron Neural } \\
\text { Network }\end{array}$ & $\begin{array}{ll}\text { RBF } & \text { Neural } \\
\text { Network } & \end{array}$ & $\begin{array}{l}\text { Feed Forward Neural } \\
\text { Network }\end{array}$ & RBF Neural Network \\
\hline Factor-> & $\begin{array}{lr}\text { 1. } & \text { Solid } \\
\text { generated. } & \text { waste }\end{array}$ & $\begin{array}{l}\text { 1.Population } \\
\text { 2.Urban } \\
\text { Population } \\
\text { 3.GDP } \\
\text { 4. Generated } \\
\text { Solid Waste. }\end{array}$ & $\begin{array}{l}\text { 1. Population of town } \\
\text { during current year. } \\
\text { 2. Waste generation } \\
\text { during current year. } \\
\text { 3.SC+ST population. } \\
\text { 4.Total received as tax. } \\
\text { 5.Longitude 6.Latitude. }\end{array}$ & $\begin{array}{l}\text { 1. Zone wise } \\
\text { Population of Nagpur } \\
\text { city. } \\
\text { 2. Zone wise solid waste } \\
\text { generated. } \\
\text { 3. Zone wise Electricity } \\
\text { Consumption. } \\
\text { 4. Zone wise slum } \\
\text { population. }\end{array}$ \\
\hline $\begin{array}{ll}\text { Dataset } & \text { on } \\
\text { various } & \\
\text { factors.-> } & \end{array}$ & $\begin{array}{lr}\text { Continuous } & 120 \\
\text { month data on } \\
\text { solid raste } \\
\text { generation has } \\
\text { been considered. }\end{array}$ & $\begin{array}{l}\text { National level } \\
\text { annual growth } \\
\text { rate has been } \\
\text { considered on } \\
\text { various factors. }\end{array}$ & $\begin{array}{l}\text { He uses two type of } \\
\text { variable, dynamic and } \\
\text { static. For dynamic } \\
\text { variable national level } \\
\text { growth rate has been } \\
\text { considered. }\end{array}$ & $\begin{array}{l}\text { We have considered zone } \\
\text { wise } \mathrm{kg} / \text { capita /year } \\
\text { rate for generated solid } \\
\text { waste. KWh/capita/year } \\
\text { for electricity } \\
\text { consumption and } \\
\% \text { of slum population to } \\
\text { zone population for slum } \\
\text { population.. } \\
\text { Zone wise population is } \\
\text { considering on } 1.2 \% \text { per } \\
\text { annum growth rate. }\end{array}$ \\
\hline
\end{tabular}

So while designing the solid waste prediction model for Nagpur city, we consider the factors and corresponding zone wise data at per capita per year basis for the accurate prediction. Above table contains comparison of model on the basis of factor and dataset taken.

Methodology:- After the carefully studying the working system of NMC, it is observed that NMC have divided Nagpur city in to 10 zones for better administration. To get the accurate result for SW prediction of the city, we decide to go for zone wise prediction of solid waste. Four important factors have been selected. Selection of factors is done on two things. 1. Importance of the factor with respect to city 2.Data availability. We have considered the following factors for each zone.

1. Population, 2. Slum population

3. Electricity consumption in KWh /capita/year.

4. Solid waste generated in ton/capita/year.

Data is considering from city profile Nagpur Municipal Corporation[2].Because of unavailability of data we have consider this data for zone wise population and slum population for the year 2011.

\begin{tabular}{|c|c|c|}
\hline Zones & $\begin{array}{c}\text { Zone wise City } \\
\text { Population }\end{array}$ & $\begin{array}{l}\text { \% Slum } \\
\text { Population }\end{array}$ \\
\hline 1 & 230624 & 20.68 \\
\hline 2 & 203242 & 42.77 \\
\hline 3 & 228664 & 16.85 \\
\hline 4 & 202753 & 56.28 \\
\hline 5 & 235000 & 34.04 \\
\hline
\end{tabular}

\begin{tabular}{|c|c|c|}
\hline 6 & 233058 & 51.49 \\
\hline 7 & 214049 & 52.97 \\
\hline 8 & 306319 & 31.99 \\
\hline 9 & 356741 & 27.19 \\
\hline 10 & 254557 & 24.81 \\
\hline Total & 2465007 & 34.84 \\
\hline
\end{tabular}

Source[2].

Zone wise population and slum population has been considered from city profile Nagpur Municipal Corporation. Population growth in India from 2001 to 2026 shall have a growth at a rate of $1.2 \%$ of per annum [13].

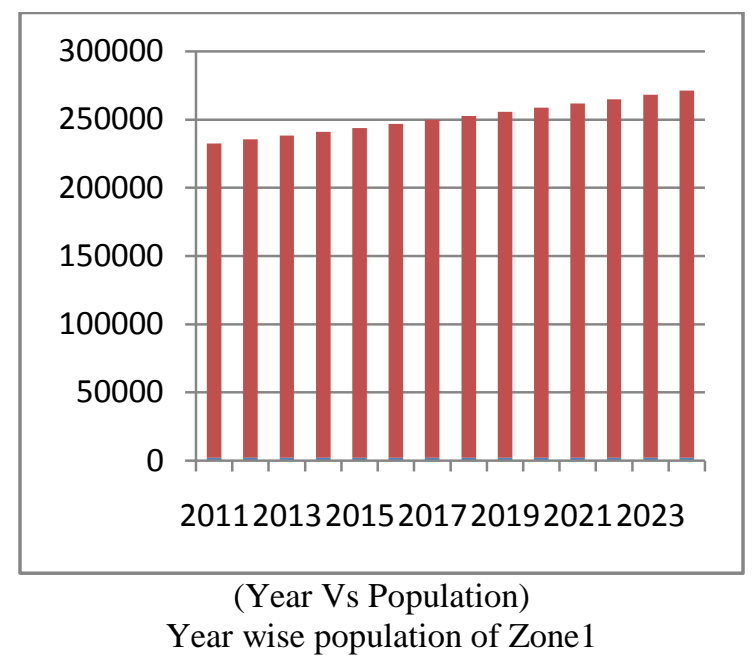


Vol. 6, Issue 1, January 2017

Zone wise slum population is calculated using $\%$ of slum population to zone population.

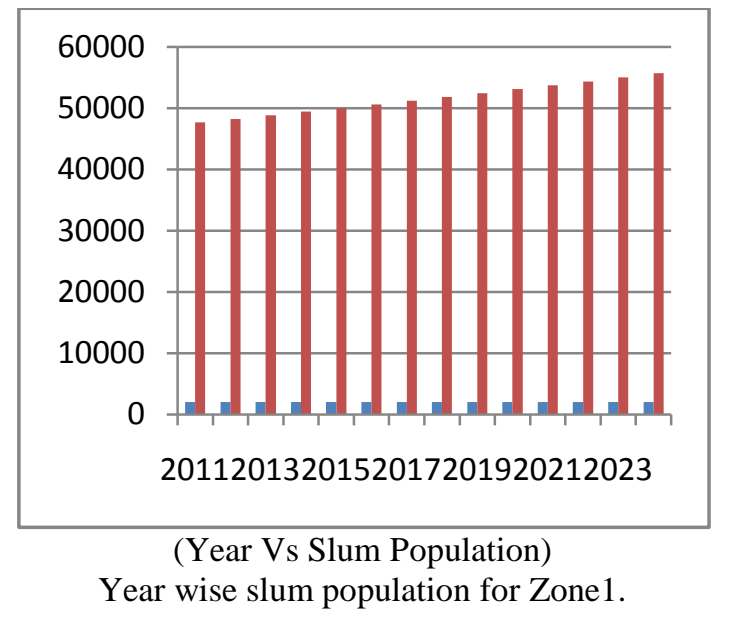

This growth rate is considered to calculate solid waste prediction for the year 2011 to 2024 .

Electricity Consumption: - There is little controversy whether GDP can be a measure of personal income because according to [13], GDP may increase while real incomes for the majority decline and the GDP is not a measure of standard of living. There is some issue on inappropriate use of Gross Domestic Product (GDP) as a measure of national well-being, something for which it was never designed, according to [4] there is a need of indicators which promote truly sustainable development. So for taking actual input of economic factor we have taken Electricity consumption of the city as a economic factor. This factor is important because it is stated in many research that economy plays major role in generation of solid waste.

In Nagpur city on an aggregate basis, in 2000-2001, total electricity consumption in 2001 was $11,50,159$, which has gone up to 36, 76,160 in 2011[1]. We consider per capita per year consumption of electricity in Nagpur city is 500 units (KWh )[28].

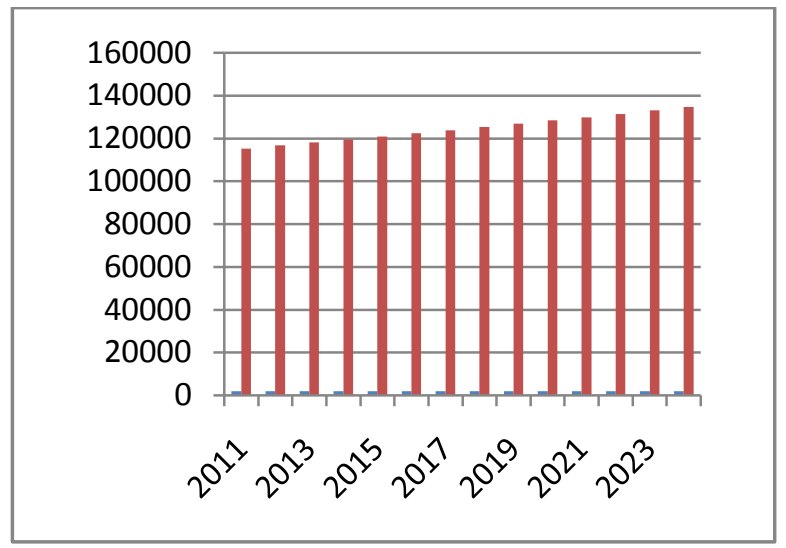

Electricity consumption for zone 1

Generated solid waste:- Each zone is having different population and capacity of solid waste generation. Below shows different zone and their SW generation capacities.
According to [3] and data published by Municipal Corporation of Nagpur city, we consider zone wise generated solid waste per capita per $\mathrm{kg}$ per day basis as follows

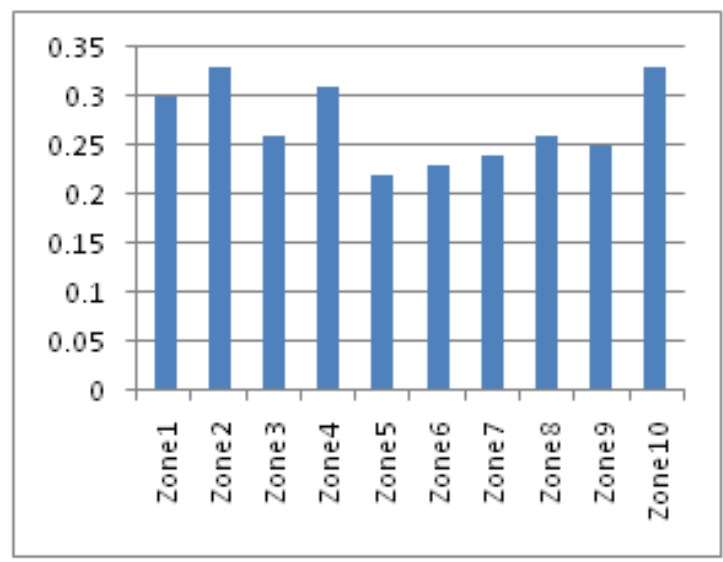

Use of RBF Neural Network in solid waste prediction: The main concept of Radial basis function is the function approximation. Initially statistical methods have been used for the prediction of solid waste, stock exchange and pattern recognition. Later on RBFNN is mostly used in time series prediction because of its very fast training and learning ability. Interpolation is one of best feature of RBFNN.

Simple architecture of RBFNN is as follows.

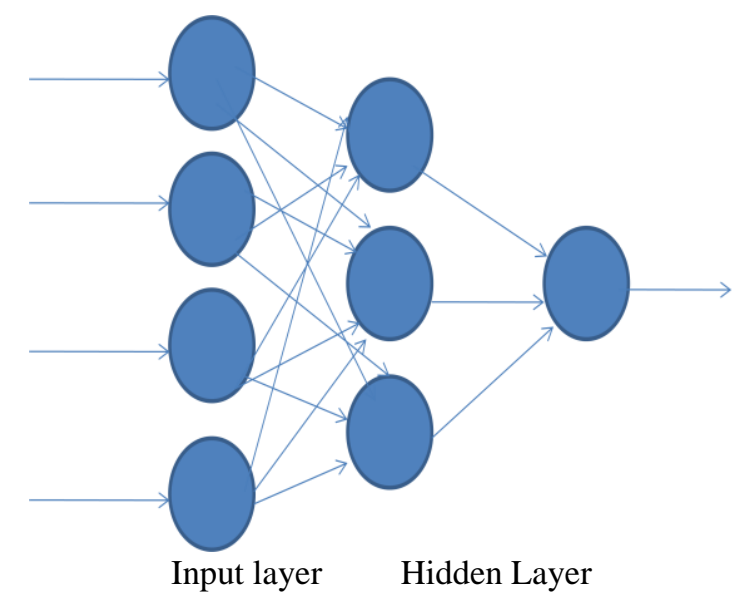

Designing of reliable Model for the Solid waste prediction in Nagpur city:-

Nagpur city is having very vast area. It is divided in to 10 zones to implement best working system. While designing the solid waste prediction model for Nagpur city, we consider four factors and dataset on the basis of per capita per year. We also kept this thing in mind during selection of variable that in the absence of past data on waste generation rates, it is difficult to design a perfect model for the SW prediction. Using MATLAB we got the view of the model for the prediction of solid waste of the city.We provide the dataset of 14 elements of each factor, Output will be generated through activation function. 
Vol. 6, Issue 1, January 2017

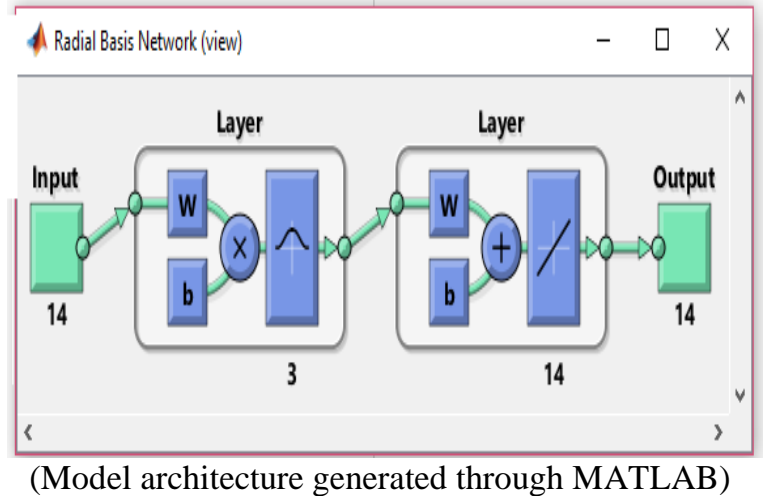

For calculation of the population we use the formula.

Population of the zone $=(\mathrm{PZ} / 100) * 1.2+\mathrm{PZ}$; $($ where $\mathrm{PZ}$ is population of the zone).

Slum population is considering as $\%$ of slum population to the zone population. ( $\mathrm{PZ} * \%$ of slum population)/100;

Zone wise Electricity consumption is getting calculated according to the $\mathrm{KWh} / \mathrm{capita/year;}$

Solid waste generated at each zone can be achieved by following function

$\mathrm{SWi}=(\sqrt{ }($ sum of factors $) /$ no. of factors $) * 100$;

Where $\mathrm{i}=1$ to 14 ;

Year wise Total solid waste of Nagpur City will be calculated by adding the $\mathrm{SW}$ generated at each zone.10

$\mathrm{SW}=\sum(\mathrm{SW}+\mathrm{SWi})$;

$$
\mathrm{i}=1
$$

Training and Testing of the neural network model: Training and testing can be obtained by using following formula.

net= newrb (Tr, Ts, MSEtrngoal);

Where $\operatorname{Tr}=$ Training data set;

$\mathrm{Ts}=$ testing data set;

MSEtrngoal=min MSE;

For ANN training we put the value of MSE

MSEtrngoal $=0.01$;

ANN training will be done according to the loop

While (MSE $<=0.01$ )

Train ANN

End.

Error can be handled as

Error $=\mid$ Actual - Predicted $\mid$

$=\mid$ Calculated by Excel-Calculated by ANN $\mid$

Total Error for individual dataset

14

$\mathrm{f}(\mathrm{ez})=$ loop $\quad \mid$ Calculated total SW by excel-

Calculated total SW by ANN $\mathrm{i}=1$

\section{RESULTS:}

The output of generated solid waste and error is given in the table obtained through MATLAB. Solid waste generated by excels and solid waste generated by ANN is used to calculate error. Error is calculated according to following formula
Total Error for individual dataset

14

$\mathrm{f}(\mathrm{ez})=$ loop $\quad \mid$ Calculated total SW by excel-

Calculated total SW by ANN |

$\mathrm{i}=1$

In this way we can get the solid waste generated at each zone of the city. Total solid waste of Nagpur city can be calculated by using the following function.

10

$\mathrm{SW}=\sum(\mathrm{SW}+\mathrm{SWi})$ $\mathrm{i}=1$

\begin{tabular}{|c|c|l|r|}
\hline Year & $\begin{array}{l}\text { Solid waste } \\
\text { by Excel }\end{array}$ & $\begin{array}{l}\text { Total Solid } \\
\text { Waste by(ANN) }\end{array}$ & Error \\
\hline 2011 & 388656.47 & 388472.00 & 184.47 \\
\hline 2012 & 390979.35 & 367741.00 & 23238.35 \\
\hline 2013 & 393316.13 & 369941.00 & 23375.13 \\
\hline 2014 & 395666.91 & 372154.00 & 23512.91 \\
\hline 2015 & 398031.76 & 374380.00 & 23651.76 \\
\hline 2016 & 400410.77 & 376620.00 & 23790.77 \\
\hline 2017 & 402804.02 & 378873.00 & 23931.02 \\
\hline 2018 & 405211.60 & 381139.00 & 24072.60 \\
\hline 2019 & 407633.59 & 383419.00 & 24214.59 \\
\hline 2020 & 410070.08 & 385713.00 & 24357.08 \\
\hline 2021 & 412521.16 & 388020.00 & 24501.16 \\
\hline 2022 & 414986.91 & 390341.00 & 24645.91 \\
\hline 2023 & 417467.42 & 392677.00 & 24790.42 \\
\hline 2024 & 419962.78 & 395026.00 & 24936.78 \\
\hline
\end{tabular}

As per the information given by the Municipal Corporation of Nagpur city we can compare the result calculated by ANN and Municipal solid waste data. We got the data for 5 years from Nagpur Municipal Corporation i.e. from 2011-12 to 2015-16 in MT.

\begin{tabular}{|l|l|l|}
\hline Year & $\begin{array}{l}\text { Solid Waste } \\
\text { calculated by ANN }\end{array}$ & $\begin{array}{l}\text { Data on Solid Waste } \\
\text { given by NMC }\end{array}$ \\
\hline 2011 & 388472.00 & 313346.38 \\
\hline 2012 & 367741.00 & 356689.01 \\
\hline 2013 & 369941.00 & 362091.42 \\
\hline 2014 & 372154.00 & 353420.82 \\
\hline 2015 & 374380.00 & 407023.56 \\
\hline 2016 & 376620.00 & \\
\hline 2017 & 378873.00 & \\
\hline 2018 & 381139.00 & \\
\hline 2019 & 383419.00 & \\
\hline 2020 & 385713.00 & \\
\hline 2021 & 388020.00 & \\
\hline 2022 & 390341.00 & \\
\hline 2023 & 392677.00 & \\
\hline 2024 & 395026.00 & \\
\hline
\end{tabular}

\section{CONCLUSION}

It is very important to know the next few year's generated solid waste for the better implementation of SWMS. NMC covers vast area, so it will be very useful for them to get 
the idea of generated solid waste of each zone to make the provision of budget, human resource and number of truck, vehicles for better planning and management of SWMS. It is true that data availability is the main problem in the prediction. If quality and quantity of data is not available then it is difficult to predict the next few years' solid waste amount.

\section{REFERENCES}

[1] Nagpur Human Development Report 2014 Prepared by Yashawantrao Chavan Academy of Development Administration (YASHADA), Pune Rashtrasant Tukdoji Maharaj Nagpur University, Nagpur.

[2] City Profile Nagpur Municipal Corporation, By: Neha Hardikar, Support: Dr. Sudha Kashelikar. All India Institute of Local SelfGovernment for Support to National Policies for Urban Poverty Reduction.

[3] Quantitative and qualitative assessment of municipal solid waste for Nagpur city Journal of Engineering Research and Studies E-ISSN 0976-7916 Pankaj R.Modak*, Prakash B. Nangare.

[4] Beyond GDP: The Need for New Measures of Progress Robert Costanza, Maureen Hart, Stephen Posner, and John Talberth. The Pardee Papers | No. 4 | January 2009.

[5] creating a 'Eco City in India :A case of Nagpur City.Divya Borkar,Shrutib S Acharya, V.P. Bhange. Department of Biotechnology, Priyadarshini Institute of Engineering \& Technology, Nagpur-19. Divya Borkar, IJPRET, 2014; Volume 2 (9): 54-61A

[6] Singh, S.K., Singh, R.S., 1998. A study on municipal solid waste and its management practices in Dhanbad-Jharia coalfield. Indian Journal of Environmental.

[7] Dayal, G., 1994. Solid wastes: sources, implications and management. Indian Journal of Environmental Protection

[8] Khan, M.Z.A. and Burney, F.A. (1989) 'Forecasting solid waste composition - an important consideration in resource recovery and recycling', Resources Conservation and Recycling, Vol. 3,

[9] Grossman, D., Hudson, J.F., Mark, D.H., Waste generation methods for solid waste collection. J. Environ. Eng. ASCE 6,

[10] Niessen, W.R., Alsobrook, A.F., Municipal and industrial refuse: composition and rates. In: Proceedings of National Waste Processing Conference, USA,

[11] Chang, N.B., Pan, Y.C., Huang, S.D., Time series forecasting of solid waste generation, J. Resource. Manag. Technol,

[12] A Model for Assessing Waste Generation Factors and Forecasting Waste Generation using Artificial Neural Networks: A Case Study of Chile Eduardo Ordóñez-Ponce, M.E. (Nat Res) Student Sandhya Samarasinghe, Ph.D. Lynn Torgerson, B.E.

[13] Prediction of Municipal Solid Waste with RBF Net Work- A Case Study of Eluru, A.P, India J. Sudhir Kumar, K. Venkata Subbaiah, and P. V. V.Prasada Rao

[14] Forecasting Generation Waste Using Artificial Neural Networks Elmira Shamshiry1, Behzad Nadi*2, Mazlin Bin Mokhtar1, Ibrahim Komoo2, Halimaton Saadiah Hashim1, Nadzri YAhya3

[15] Modeling Energy Content of Municipal Solid Waste Using Artificial Neural Network 1 T. Ch. Ogwueleka, 2 F. N. Ogwueleka

[16] Forecasting of Municipal Solid Waste Generation for Medium Scale Towns Located in the State of Gujarat, India Vatsal Patel Srinivasarao Meka

[17] Prediction of Municipal Solid Waste Generation by Use of Artificial Neural Network: A Case Study of Mashhad Jalili Ghazi Zade, M.1 and Noori, R.2*

[18] Waste Prognosis based on Socio-economic indicators by Artificial Neural Network in India R.Nithya Dr.S.R.R.Senthil Kumar, A.Velumani,

[19] Comparison of Neural Network and Principal ComponentRegression Analysis to Predict the Solid Waste Generation in Tehran *R Noori, MA Abdoli, M Jalili Ghazizade, R Samieifard

[20] A Comparative Analysis of Neural Networks and Statistical Methods for Predicting Consumer Choice Patricia M. West, Patrick L. Brockett, Linda L. Golden
[21] Artificial Neural Network and its Application Girish kumar jha I.A.R.I New Delhi.

[22] Hair, Anderson, Tatham, Black, (1998), "Multivariate Data Analysis,'Pearson Education press.

[23] Kalyani Dacha (2007), "Causal Modeling of Stock Market Prices using Neural Networks and Multiple Regressions: A Comparison Report" Finance India, Vol. xxi.

[24] Mendenhall and Beaver, Introduction to Probability and Statistics, Ninth Edition, International Thomson Publishing, 1994.

[25] An Analysis of the Performance of Artificial Neural Network Technique for Stock Market Forecasting Kunwar Singh Vaisla Dr. Ashutosh Kumar Bhatt.

[26] Artificial Neural Network-based Time Series Analysis Forecasting for the Amount of Solid Waste in Bangkok. IEEE conference publication. Maleerat Sodanil \& Paiboon Chatthong Faculty of Information Technology King Mongkut's University of Technology North Bangkok Thailand.

[27] Time series prediction competition: The CATS benchmark Neuro computing 70 (2007) 2325-2329 Editorial / Neurocomputing.

[28] Nagpur Local Renewable Activities and City Energy Status Report Local Renewables Model Communities Network Project International Workshop 28-30 Nov, Nagpur Presentation by Lokesh Chandra, IAS Commissioner Nagpur Municipal Corporation, Nagpur. 